\title{
Grounding-zone wedges and mega-scale glacial lineations in the Mertz Trough, East Antarctica
}

\author{
K. McMULLEN ${ }^{1}$, E. DOMACK ${ }^{2 *}$, A. LEVENTER ${ }^{3}$, C. LAVOIE ${ }^{4}$, M. CANALS ${ }^{5}$ \\ ${ }^{1}$ Woods Hole Oceanographic Institution, 266 Woods Hole Road, Woods Hole, Massachusetts 02543, USA \\ ${ }^{2}$ College of Marine Science-University of South Florida, 140 7th Avenue South, St. Petersburg, Florida, 33701, USA \\ ${ }^{3}$ Department of Geology, Colgate University, 13 Oak Drive, Hamilton, New York 13346, USA \\ ${ }^{4}$ Department of Geosciences/CESAM, University of Aveiro, Aveiro, 3810-193, Portugal \\ ${ }^{5}$ GRR Geociències Marines, Universitat de Barcelona, Barcelona, Spain \\ *Corresponding author (e-mail: edomack@usf.edu)
}

\begin{abstract}
Glacial erosion and deposition have shaped the Mertz Trough, East Antarctica, where seafloor grounding-zone wedges (GZWs) are associated with mega-scale glacial lineations (MSGLs) (McMullen et al. 2006). GZWs form along glacial margins at the transition to ice shelves during still-stands and consist of glacially transported sediment that is deposited on the icedistal side of the wedge (Powell \& Domack 2002). MSGLs are parallel elongated bedforms that typically form in soft sediments and beneath rapidly flowing ice streams (Clark 1993; Canals et al. 2000; Clark et al. 2003). They are found in glacial troughs where they run parallel to the trough axis. MSGLs are generally 6 to $>100 \mathrm{~km}$ long, 200 to $1300 \mathrm{~m}$ wide, and spaced 0.3 to $5 \mathrm{~km}$ crest-to-crest (Clark et al. 2003; McMullen et al. 2006).
\end{abstract}

\section{Description}

The Mertz Trough is located perpendicular to the George V coast of Wilkes Land, East Antarctica (Fig. 1a, b). Multibeam-bathymetric imagery reveals a number of distinct features on the seafloor including several parallel elongated ridge and groove pairs, two sinuous sediment build-ups with streamlined bedforms at their surface, and depressions (Fig. 1c).

Five main parallel, elongated, straight ridge and groove pairs in the northern, seaward part of the study area are 14 to $20 \mathrm{~km} \mathrm{long,} 500 \mathrm{~m}$ wide, and $20 \mathrm{~m}$ high. They are oriented north-south and have a lateral spacing of 1 to $1.5 \mathrm{~km}$. South of these bedforms are two large, sinuous build-ups (GZWA and GZW-B) oriented northwest-southeast. GZW-A and GZW-B are over $30 \mathrm{~km}$ long and up to $80 \mathrm{~m}$ high with steep downward steps facing northeast (seaward) and more gradually sloped southwest (landward) sides. A $2.5-\mathrm{m}$ core in GZW-B (KC-2) shows that it is composed of diamicton capped by a diatom mud and ooze (Fig. 1c; McMullen et al. 2006). Smaller sediment build-ups with similar orientation and slope profiles to the larger GZWs are also visible (Fig. 1c). Parallel ridges and grooves that are several $\mathrm{km}$ long and 100 to $200 \mathrm{~m}$ wide, similar to, but smaller than, those in the northern part of the study area, appear to the south of GZW-A, where they are oriented north-northeast and are less conspicuous than those to the north. Centered within GZW-A and GZW-B are a breach point, scoured from a meltwater channel, and a depression, respectively, located where the relief of each build-up above the surrounding seafloor is about $40 \mathrm{~m}$. The height of the large build-ups increases up to $80 \mathrm{~m}$ to the northwest of the depression and remains about $40 \mathrm{~m}$ to the east. The breach point in GZW-A is about $1 \mathrm{~km}$ wide, $15 \mathrm{~m}$ deep, and has an associated fan extending in a seaward direction, while the centered depression in GZW-B has a larger diameter of about 5 $\mathrm{km}$ and is not as well defined.

\section{Interpretation}

The parallel, elongated ridges and grooves to the north of the swath-mapped area are interpreted to be MSGLs, like similar structures in the Ross Sea and from the Gerlache Strait to Boyd Strait (Shipp et al. 1999; Canals et al. 2000). They indicate past ice streaming, flowing in a northerly direction, likely during the Last Glacial Maximum (LGM). This ice stream flowed out of the Mertz and Ninnis glacier systems from the south.

GZW-A and GZW-B, the large sinuous sediment build-ups oriented roughly perpendicular to the MSGLs are grounding-zone wedges marking areas where the ice sheet paused during its retreat. Their large size may reflect a sedimentary-basin source. Minor recession lines are marked by the smaller sediment build-ups, the development of which was possibly influenced by the occurrence of the MSGLs or shorter duration of still stands. The streamlined megaflute bedforms in the sediment inversely mirror the grooved ice base. As the ice lifts off the seafloor, the long keel of ice that forms a groove in the sediment reaches into deeper water than ice directly above a ridge of sediment, which could produce scalloped grounding zones. GZW-A marks the location where ice-flow directions changed from northerly to north-northeasterly during ice retreat, as evidenced by the orientations of MSGLs to the north and south of this feature. The breach point within GZW-A resulted from scouring of the GZW by channelized subglacial meltwater (McMullen et al. 2006; Le Brocq et al. 2013). The breach point has a small associated fan seaward of the breach, likely formed from sediment transported by glacial meltwater (Powell \& Domack 2002). The centered depression within GZW-B marks the place where the grounding zone shifts southward, which is aligned with the breach point in GZW-A with respect to the ice-flow direction. The depression in GZW-B is larger in diameter and could have been formed by a greater volume of meltwater that dispersed its sediment load further or this feature could just be the backslope of an older, more northerly grounding zone.

The sea-floor features in the Mertz Trough illustrate the glacial history of the region, which was once covered by grounded ice. During the LGM, an ice stream flowed northward through the overdeepened trough, forming MSGLs. As the ice retreated southward, it paused in at least two places and deposited the main GZWs. Subglacial meltwater breached GZW-A, scoured a depression, and deposited a small sediment fan. After GZW-A was deposited, the ice-flow direction shifted towards the north-northeast as the ice sheet retreated further to the south, depositing sediment in small buildups representing minor grounding zones. The parent ice stream became less prominent with recession, as the MSGLs are less conspicuous to the south During another pause in recession, GZW-B was deposited and subglacial meltwater may have eroded a similar, though larger, depression. The ice sheet continued retreating and flow directions shifted towards the northeast.

\section{References}

CANALS, M., URGELES, R. \& CALAFAT, A.M. 2000. Deep sea-floor evidence of past ice streams off the Antarctic Peninsula. Geology, 28, 31-34.

CLARK, C.D. 1993. Mega-scale glacial lineations and cross-cutting iceflow landforms. Earth Surface Processes and Landforms, 18, 1-29.

CLARK, C.D., TULACZYK, S., STOKES, C.R. \& CANALS, M. 2003. A groove-ploughing theory for the production of mega-scale glacial lineations, and implications for ice-stream mechanics. Journal of Glaciology, 49, 240-256.

LE BROCQ, A.M., ROSS, N., et al. 2013. Evidence from ice shelves for channelized meltwater flow beneath the Antarctic Ice Sheet. Nature Geoscience, 6, 945-948.

McMULLEN, K., DOMACK, E., LEVENTER, A., OLSON, C., DUNBAR, R. \& BRACHFELD, S. 2006. Glacial morphology and sediment formation in the Mertz Trough, East Antarctica. Palaeogeography, Palaeoclimatology, Palaeoecology, 231, 169-180.

POWELL, R. \& DOMACK, E. 2002. Modern glaciomarine environments. In Menzies, J. (ed.), Modern and past glacial environments. Butterworth-Heinemann, Boston, pp. 361-389.

SHIPP, S., ANDERSON, J. \& DOMACK, E. 1999. Late PleistoceneHolocene retreat of the West Antarctic ice-sheet system in the Ross Sea: Part 1. Geophysical results. GSA Bulletin, 111, 1486-1516. 


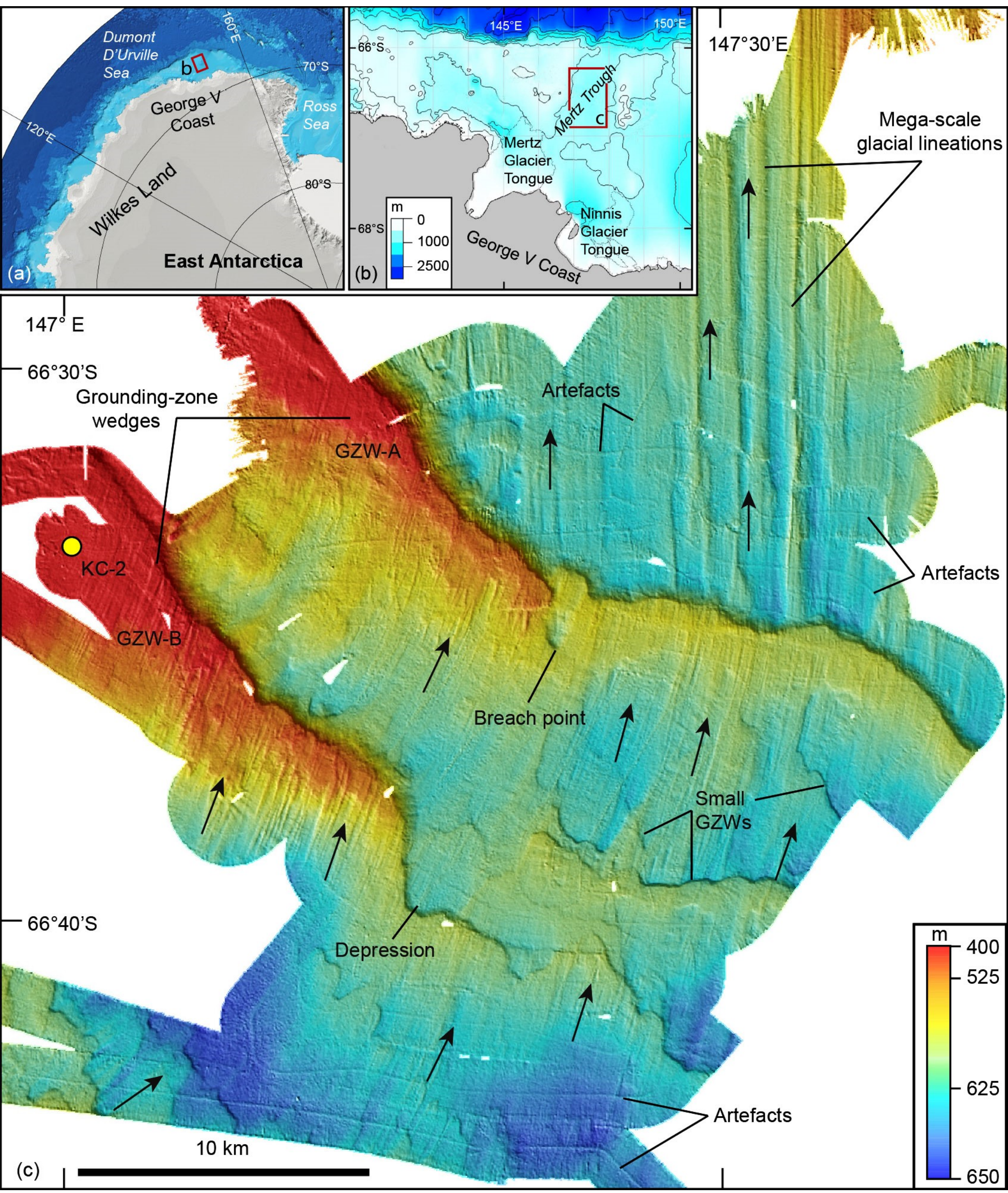


From: DOWDESWELL, J.A., CANALS, M., JAKOBSSON, M., TODD, B.J., DOWDESWELL, E.K. \& HOGAN, K.A. (eds) Atlas of Submarine Glacial Landforms: Modern, Quaternary and Ancient. Geological Society, London, Memoirs, 46, http://doi.org/10.1144/M46.

Fig. 1. Multibeam-bathymetric imagery of the central Mertz Trough, East Antarctica. (a) Location of study area (red box; map from IBCSO v. 1.0). (b) General bathymetry map of the Mertz Trough region. (c) Grounding-zone wedges (GZW-A and GZW-B) with streamlined megaflute bedforms at their surface and MSGLs in between and off GZWs. Black arrows indicate direction of ice flow, which is roughly opposed to ice retreat direction. Location of Kasten sediment core (KC-2) is shown by yellow circle. Nadir artefacts that could not be removed during processing are also shown. Acquisition system SeaBeam 2112. Frequency $12 \mathrm{kHz}$. Grid-cell size $35 \mathrm{~m}$. 